\title{
SGK1 wt Allele
}

National Cancer Institute

\section{Source}

National Cancer Institute. SGK1 wt Allele. NCI Thesaurus. Code C101560.

Human SGK1 wild-type allele is located in the vicinity of $6 \mathrm{q} 23$ and is approximately $149 \mathrm{~kb}$ in length. This allele, which encodes serine/threonine-protein kinase Sgk1 protein, is involved in the modulation of both protein phosphorylation and signaling. Aberrant expression of the gene may be associated with hypertension and diabetic nephropathy. 